\title{
Dampak Luas Lahan, Harga Jual, Hasil Produksi, dan Biaya Produksi Terhadap Pendapatan Petani Padi Jurnal Ecces
}

\author{
Sitti Aisyah ${ }^{1}$ \\ Asriani Yunus ${ }^{2}$ \\ 1,2, Program Studi Ilmu Ekonomi \\ Fakultas Ekonomi dan Bisnis Islam Universitas Islam Negeri Alauddin Makassar \\ Jl. Yasin Limpo, No. 36 Samata, Gowa, Sulawesi Selatan \\ E-mail :sitti.aisyah.s@uin-alauddin.ac.id ${ }^{1}$, asrianiyunus18602@gmail.com²
}

\section{Abstrak: Dampak Luas Lahan, Harga Jual, Hasil Produksi, dan Biaya Produksi Terhadap Pendapatan Petani Padi}

Petani diperhadapkan dengan berbagai permasalahan, yang terus menggerus pendapatan mereka dari waktu ke waktu. Ketika masa panen telah tiba, hasil produksi padi tidak sesuai dengan apa yang diharapkan para petani. Semakin berkurangnya lahan pertanian yang disebabkan banyaknya alih fungsi lahan, akibat pembangunan perumahan, pendapatan yang diperoleh petani tidak menentu sedangkan pengeluaran mereka semakin meningkat dari hari ke hari. Selain itu, pertumbuhan penduduk yang semakin tinggi dan produksi padi yang dihasilkan tidak menentu, serta melaratnya petani dalam hal pembiayaan pertanian yang membuat petani terlibat hutang. Persoalan-persoalan itu menjadi, tantangan besar bagi penghidupan petani saat ini. Tujuan penelitian ini untuk mengetahui seberapa besar pengaruh luas lahan, harga jual, hasil produksi, dan biaya produksi terhadap tingkat pendapatan petani padi di Kecamatan Majauleng Kabupaten Wajo. Jenis penelitian yaitu kuantitatif explanatory method, dengan menggunakan regresi linear berganda dengan menggunakan bantuan software SPSS 24 for windows. Hasil penelitian menunjukkan bahwa secara simultan variabel luas lahan, harga jual, hasil produksi, dan biaya produksi berpengaruh signifikan dan berhubungan positif terhadap pendapatan petani. Dan secara parsial luas lahan dan harga jual, serta hasil produksi berpengaruh signifikan dan berhubungan positif terhadap pendapatan petani. Sedangkan biaya produksi secara parsial berpengaruh positif dan berhubungan negatif terhadap pendapatan petani. Untuk meningkatkan produksi bagi petani, dari pihak pemerintah ataupun swasta harus mengarahkan petani dalam hal pemasaran hasil panen yang diperoleh serta cara penggunaan teknologi dibidang produksi, seperti penggunaan bibit unggul baik itu secara kualitas maupun kuantitas.

Kata Kunci: Pendapatan, Luas Lahan, Harga, dan Produksi. 


\section{Abstract: Impact of Land Area, Selling Prices, Results Production, and Production Costs to Revenue Of Rice Farmers}

Farmers are faced with various problems, which continue to erode their income from time to time. When the harvest time has arrived, the yield of rice production does not match what farmers expect. The decreasing amount of agricultural land is caused by a lot of land conversion, due to housing development, the income earned by farmers is uncertain while their expenses are increasing day by day. In addition, population growth is higher and the production of rice produced is uncertain, as well as poor farmers in terms of agricultural financing that makes farmers involved in debt. These problems become a big challenge for farmers' livelihoods today. The purpose of this study was to determine how much influence the area of land, selling prices, production results, and production costs to the level of income of rice farmers in Majauleng District, Wajo Regency. This type of research is quantitative descriptive or explanatory method, using multiple linear regression using SPSS 24 for windows software. The results showed that simultaneous variables of land area, selling price, production results, and production costs had a significant effect and positively related to farmers' income. And partially the area of land and the selling price, as well as production results have a significant effect and positively related to farmers' income. While the production costs partially have a positive effect and negatively related to farmers' income. To increase production for farmers, the government or the private sector must direct farmers in terms of marketing the harvests obtained and how to use technology in production, such as the use of quality seeds both in quality and quantity.

Keywords: Income, Land, Price, Production.

\section{PENDAHULUAN / INTRODUCTION}

Sulawesi Selatan merupakan provinsi yang terkenal sebagai salah satu penghasil tanaman padi terbesar di Kawasan Timur Indonesia. Predikat sebagai lumbung padi nasional mengukuhkan posisi Sulawesi Selatan sebagai produsen tanaman pangan yang cukup potensial di Indonesia bagian Timur. Peningkatan produksi tanaman pangan lebih diarahkan pada tanaman padi dan jagung. Padi telah menjadi komoditas strategis dalam kehidupan di Indonesia, peran padi selain sebagai sumber pangan pokok juga menjadi sumber penghasilan bagi petani dan sebagai kebutuhan hidup sehari hari bagi jutaan penduduk di Indonesia.

Kecamatan Majauleng adalah salah satu pengembang padi di Kabupaten Wajo. Sebagian besar masyarakatnya sebagai petani. Semakin berkembangnya sektor pertanian, diharapkan mampu meningkatkan produktivitas petani, dengan perkembangan tersebut diharapkan meningkatnya pula pendapatan yang diperoleh petani padi atau dengan kata lain hasil produksi sesuai dengan harapan petani. Pendapatan merupakan salah satu indikator ekonomi, dengan kata lain arah pembangunan ekonomi yaitu mengusahakan agar 
produktivitas petani padi dapat meningkat, yang diikuti dengan meningkatnya pula pendapatan yang diperolehnya.

Tabel 1 Luas Lahan dan Produksi Padi di Kecamatan Majauleng dari Tahun 2013-2017

\begin{tabular}{ccc}
\hline Tahun & Luas Lahan $(\mathrm{Ha})$ & Produksi (ton) \\
\hline 2013 & 12.599 & 80.691 \\
2014 & 12.833 & 74.739 \\
2015 & 12.523 & 51.316 \\
2016 & 23.115 & 59.133 \\
2017 & 17.678 & 48.223 \\
\hline
\end{tabular}

Sumber: BPS Kabupaten Wajo 2018.

Luas lahan di Kecamatan Majauleng mengalami penurunan di tahun 2015 yaitu sebesar 12.523 Ha tetapi meningkat derastis di tahun 2016 yaitu 23.115 Ha. Kemudian menurun ditahun 2017 yaitu $17.678 \mathrm{Ha}$. Hasil produksi menurun pada tahun 2015 yaitu sebesar 51.133 ton kemudian ditahun berikutnya mengalami penurununan yaitu 48.223 ton. Ketika naik turunnya produksi padi di Kecamatan Majauleng tergantung pada kondisi cuaca, serangan hama, penyakit tanaman, dan penggunaan faktor-faktor produksi yang tidak optimal sehingga mengakibatkan pendapatan yang diperoleh petani juga tidak menentu. Hal ini sejalan dengan temuan Faisal dan Nursini (2018) bahwa minimnya luas lahan garapan petani berdampak pada tingkat pendapatan yang rendah. Petani yang menggarap luas lahan di bawah dari 100 are, maka rata-rata pendapatannya di bawah dari garis kemiskinan atau dipastikan miskin.

Luas lahan merupakan faktor kunci dalam usaha pertanian. Semakin luas lahan (yang digarap/ditanami), semakin besar jumlah yang dihasilkan oleh lahan tersebut Ketika luas lahan padi setiap tahunnya berkurang, maka akan mempengaruhi produksi yang akan di peroleh oleh para petani, dan ketika hasil produksi padi tidak sesuai dengan apa yang diharapkan maka pendapatan petani juga akan menurun seiring dengan harga yang dipasaran yang semakin hari semakin meningkat. Harga merupakan salah satu faktor untuk menentukan pendapatan petani. Logikanya, jika harga di pasar rendah maka harga beli dari petani juga rendah. Ini membuat keuntungan yang akan diperoleh petani semakin kecil megingat biaya produksi tanam yang semakin tinggi. Adapun permasalahan yang dialami 
oleh petani di Kecamatan Majauleng Kabupaten Wajo dalam memproduksi padi yaitu ketika masa panen telah tiba hasil produksi padi tidak sesuai dengan apa yang diharapkan para petani. semakin berkurangnya lahan pertanian yang disebabkan banyaknya alih fungsi lahan akibat pembangunan perumahan, pendapatan yang diperoleh petani tidak menentu sedangkan pengeluaran yang semakin meningkat setiap harinya, pertumbuhan penduduk yang semakin tinggi dan produksi padi yang dihasilkan tidak menentu serta melaratnya petani dalam hal pembiayaan pertanian yang membuat petani terlibat hutang.

\section{TINJAUAN TEORITIK / LITERATURE REVIEW}

\section{Teori Pendapatan}

Menurut Adam Smith dan David Ricardo dalam Jhingan (2012) pendapatan merupakan unsur yang sangat penting dalam sebuah usaha, karena dalam melakukan suatu usaha tentu ingin mengetahui nilai atau jumlah pendapatan yang diperoleh selama melakukan usaha tersebut. Distribusi pendapatan digolongkan dalam tiga kelas sosial yang utama : pekerja, pemilik modal, dan tuan tanah. Ketiganya menentukan 3 faktor produksi, yaitu tenaga kerja, modal, dan tanah. Penghasilan yang diterima setiap faktor produksi dianggap sebagai pendapatan masing masing keluarga terlatih terhadap pendapatan nasional. Pendapatan yaitu jumlah barang dan jasa yang memenuhi tingkat hidup masyarakat, dimana dengan adanya pendapatan yang dimiliki masyarakat dapat memenuhi kebutuhan, dan pendapatan rata-rata yang dimiliki oleh tiap jiwa disebut juga dengan pendapatan perkapita serta menjadi tolak ukur kemajuan atau perkembangan ekonomi.

Namun berbeda dengan Pareto dalam Mankiw (2007) yang menegaskan bahwa distribusi pendapatan pada prinsipnya berdasarkan besarnya (size distribution of income), yaitu distribusi pendapatan diantara rumah tangga yang berbeda, tanpa mengacu pada sumber-sumber pendapatan atau kelas sosialnya, sebagaimana yang diungkapkan sebelumnya oleh Ricardo, sebab ketidakmerataan distribusi pendapatan terjadi cukup besar disemua negara.

\section{Luas Lahan}

Menurut Ricardo dalam Alvio (2017), Soekartawi (2003) dan Silvira (2014) bahwa petani merupakan kelas produktif dalam piramida perekonomian, sebab petani lah yang menciptakan nilai dalam proses produksi, sementara kaum pedagang hanya memindahkan proses distribusi dari sebuah barang. Petani merupakan pemilik dan pengelola lahan pertanian. Sementara, luas lahan akan mempengaruhi skala usaha, dimana usaha ini pada 
akhir-nya akan mempengaruhi efesien atau tidaknya suatu usaha pertanian. makin luas lahan yang dipakai sebagai usaha pertanian maka lahan tersebut semakin tidak efesien. Hal ini didasarkan pada pemikiran bahwa luasnya lahan mengakibatkan upaya melakukan tindakan yang mengarah pada segi efesien akan berkurang. Sebaliknya pada lahan yang sempit upaya pengawasan terhadap penggunaan faktor produksi semakin baik, sehingga usaha pertanian ini lebih efesien. Namun dari lain sisi semakin luas lahan semakin banyak pengasilan dari petani padi.

Sementara hal tersebut ditentang oleh Marshall dalam Salvatore (2002) luas lahan bukan sebagai salah satu faktor produksi yang mempengaruhi hasil pertanian, dan tidak mempunyai kontribusi yang cukup besar terhadap usaha tani. Besar kecilnya produksi dari usaha tani antara lain dipengaruhi oleh prouktifitas lahan yang digunakan, sebab luas areal tanam dan produksi per hektar dipengaruhi oleh perubahan harga dan produksi per hektar yang tentunya dipengaruhi juga oleh produktifitas modal yang dimiliki. Intinya produktifitas menjadi kunci dari sebuah aktifitas produksi, sementara volume produksi seringkali menghasilkan profit yang lebih rendah, dibandingkan hasil produksi yang berkualitas yang memiliki tingkat produktifitas yang lebih tinggi.

\section{Harga}

Defenisi harga menurut Mankiw (2007) harga adalah elemen pemasaran campuran yang paling mudah untuk mengatur keistimewaan suatu produk. Harga juga mengkomunikasikan kepada pasar penempatan nilai produk atau merek yang dimaksud suatu perusahaan.Teori harga merupakan teori ekonomi yang menerangkan tentang perilaku harga atau jasa. Isi dari teori harga pada umunya adalah harga suatu barang atau jasa yang pasarnya kompetitif tinggi rendahnya ditentukan oleh permintaan dan penawaran. Harga suatu barang dan jumlah barang yang diperjual belikan, yang ditentukan oleh permintaan dan penawaran dari barang tersebut. Karena itu, untuk menganalisis mekanisme penentuan harga dan jumlah barang yang diperjual-belikan dipasar perlu secara serentak dianalisis permintaan dan penawaran terhadap suatu barang tertentu yang ada dipasar. Teori harga merupakan teori ekonomi yang menerangkan tentang perilaku harga atau jasa. Isi dari teori harga pada umunya adalah harga suatu barang atau jasa yang pasarnya kompetitif tinggi rendahnya ditentukan oleh permintaan dan penawaran. 


\section{Produksi}

Menurut Todaro (2003), Sudantoko (2009), Suryana (2001) mencoba menggambarkan secara umum tentang produksi yaitu berkaitan dengan cara bagaimana sumber daya (masukan) dipergunakan untuk menghasilkan produk (keluaran). Produksi merupakan hasil akhir dari proses atau aktivitas ekonomi dengan memanfaatkan beberapa masukan atau input yang ada. Produksi atau memproduksi yaitu menambah kegunaan (nilai guna) suatu barang. Kegunaan suatu barang akan bertambah apabila memberikan manfaat baru atau lebih baik dari bentuk semula. Lebih spesifiknya lagi produksi yaitu proses kombinasi dan koordinasi material-material dan kekuatan-kekuatan (input, faktor, sumber daya, atau jasa-jasa produksi) dalam pembuatan suatu barang atau jasa (output atau produk)

Namun sedikit berbeda menurut Adam Smith dalam Teguh (2009), Rahim (2007), Sakirno (2013) yang secara khas menggambarkan produksi adalah suatu teori yang mengatur dan menjelaskan suatu proses produksi. Hal ini dikarenakan kaum klasik percaya bahwa "Supply creates its own demand". Pernyataan kaum klasik tersebut tersebut menunjukkan bahwa berapapun yang diproduksi oleh produsen (sektor swasta) akan mampu diserap atau dikonsumsi oleh rumah tangga. Teori produksi yang sederhana menggam-barkan tentang hubungan antara tingkat produksi suatu barang dengan jumlah tenga kerja yang digunakan untuk menghasilkan berbagai tingkat produksi barang tersebut. Produksi dalam arti luas adalah kegiatan menciptakan nilai. Sedangkan dalam arti sempit adalah kegiatan produksi berarti menghasilkan suatu komoditi tertentu dengan menggunakan faktor-faktor produksi.

Nurkse (1953), Schultz (1953), dan Rostow (1960), Murphy, Shleifer, dan Vishny (1989), Kongsamut, Rebelo dan Xie (2001), Gollin, Parente, dan Rogerson (2002), Bustos, Caprettini dan Ponticelli (2016) dalam pandangannya yang mencoba mensintesa hal tersebut bahwa produksi yang massif di sektor pertanian merupakan, stimulus untuk menciptakan basis produksi yang kuat pada sektor industri, untuk proses produksi masa depan. Dimana, mekanisme produktivitas pertanian dapat mempercepat pertumbuhan industri dan sektor ekonomi pertanian. Pertumbuhan produksi pertanian meningkatkan pendapatan per kapita, yang menghasilkan permintaan untuk barang-barang manufaktur jika preferensi tidak homotetis. Permintaan relatif yang lebih tinggi untuk pabrik menghasilkan realokasi tenaga kerja jauh lebih besar di sektor pertanian. 


\section{Biaya Produksi}

Menurut Mowen (2004), Mulyati (2013) dan Puguh (2014) biaya produksi adalah biaya yang berkaitan dengan pem-buatan barang dan penyediaan jasa. Biaya produksi dapat diklasifikasi sebagai biaya produksi langsung, biaya tenaga kerja langsung dan biaya overhead pabrik. Menurut Pengertian tersebut dapat dilihat dari beberapa unsur yang terkandung didalamnya, yaitu merupakan hal yang terjadi atau potensial akan terjadi dan pengorbanan tersebut dilakukan untuk mencapai tujuan tertentu dimasa yang akan datang, dengan tujuan untuk mem peroleh pendapatan, biaya merupakan pengorbanan sumber ekonomi berupa kas atau ekuivaleannya yang dapat diukur dalam satuan moneter uang.Biaya produksi adalah jumlah dari tiga unsur biaya yaitu biaya produksi langsung, biaya tenaga kerja langsung dan biaya overhead pabrik. Biaya produksi langsung dan biaya tenaga kerja langsung dapat digolongkan kedalam golongan utama (primer cost). Sedangkan biaya tenaga kerja langsung dan biaya overhead pabrik dapat digabungkan kedalam golongan konversi (conversion cost) yang mencerminkan biaya pengubahan bahan langsung menjadi barang atau hasil produksi. Daniel menyatakan bahwa dalam usaha tani dikenal dua macam biaya, yaitu biaya tunai atau biaya yang dibayarkan dan biaya yang tidak tunai atau biaya yang tidak dibayarkan. Adapun biaya yang dibayarkan adalah biaya yang dikeluarkan untuk membayar upah tenaga kerja luar keluarga, biaya untuk pembelian input produksi seperti bibit, pupuk, obat-obatan dan lain-lain. Kadang-kadang juga termasuk biaya untuk iuran pema kaian air dan irigasi, pembayaran zakat, sewa lahan dan lain-lain.

Sedangkan berbeda dengan Suratiyah (2006) menyatakan bahwa modal (biaya) yang tersedia berhubungan langsung dengan peran petani sebagai manajer dan juru tani dalam mengelola usaha taninya agar dapat menghasilkan output yang sesuai dengan harapan. Seberapa besar tingkat penggunaan faktor produksi tergantung pada modal yang tersedia baik itu tunai ataupaun non tunia. Menurut Soekartawi biaya dalam usaha tani diklasifikasikan dalam tiga golongan yaitu: a) Biaya uang dan biaya in natura, b) Biaya tetap dan biaya variabel, dan c) Biaya rata-rata dan biaya marginal. Biaya tetap adalah jenis biaya yang besar kecilnya tidak tergantung pada besar kecilnya produksi, misalnya sewa atau bunga tanah yang berupa uang. Sedangkan biaya variabel adalah biaya yang besar kecilnya berhu bungan langsung dengan besarnya produksi, misalnya bibit, pupuk, pes tisida dan lain-lain. Biaya rata-rata adalah hasil bagi antara biaya total dengan jumlah produk yang 
dihasilkan. Sedangkan biaya marginal adalah biaya tambahan yang dikelu arkan petani untuk mendapatkan tam bahan satu satuan produk pada satu tingkat produksi tertentu.

\section{METODE PENELITIAN / METHODS}

Metode penelitian yang digunakan dalam penelitian ini adalah metode deskriptif kuantitatif. Data yang digunakan adalah data primer dan sekunder.Metode pengumpulan data dilakukan melalui cara, yaitu: 1) Observasi, 2) Dokumentasi, 3) Kuisioner. Populasi yang diambil oleh peneliti dalam penelitian ini adalah semua petani padi yang berada di Desa Botto Benteng Kecamatan Majauleng Kabupaten Wajo yang berjumlah 184 petani. Metode simple random sampling merupakan pengambilan sampel secara acak. Penelitian ini menggunakan pengambilan metode random, dimana pengambilan random adalah bahwa semua populasi memiliki kesempatan yang sama untuk diambil sebagai sampel. Penentuan sampel dengan menggunakan rumus slovin dengan taraf signifikansi $10 \%$ atau dengan nilai 0,1 , digunakan dalam penelitian ini yaitu sebanyak 126 petani padi yang dianggap sudah mewakili seluruh petani yaitu sebanyak 184 petani padi. Data diperoleh melalui jawaban kuisioner yang diperoleh dari para petani padi yang menjadi objek penelitian beserta hasil wawancara dengan pihak-pihak terkait. Lokasi yang menjadi tempat penelitian ini adalah Desa Botto Benteng Kecamatan Majauleng Kabupaten Wajo Sulawesi Selatan.

\section{HASIL DAN PEMBAHASAN / DISCUSSION}

Tabel 1 Hasil Analisis Regresi

Coefficients $^{\mathrm{a}}$

\begin{tabular}{|llccccc}
\hline \multirow{2}{*}{ Model } & \multicolumn{2}{c}{$\begin{array}{c}\text { Unstandardized } \\
\text { Coefficients }\end{array}$} & $\begin{array}{c}\text { Standardized } \\
\text { Coefficients }\end{array}$ & t & Sig. \\
\cline { 3 - 5 } & \multicolumn{1}{c}{ B } & Std. Error & Beta & & \\
\hline 1 & (Constant) & -4.409 & .618 & & -7.139 & .000 \\
& Luas Lahan & .094 & .020 & .069 & 4.604 & .000 \\
& Harga Jual & 1.785 & .075 & .149 & 23.817 & .000 \\
& Hasil Produksi & 1.235 & .018 & 1.137 & 69.969 & .000 \\
& Biaya Produksi & -.321 & .010 & -.317 & -30.985 & .000 \\
\hline
\end{tabular}

Dependent Variable: Pendapatan

Sumber : Data Primer Diolah, 2019, Output SPSS 24.

Dari persamaan regresi berganda di atas dapat dilihat sebagai berikut :

a) Nilai Konstanta (a) 
Nilai konstanta sebesar -4.409 berarti jika Luas Lahan, Harga Jual, Hasil Produksi dan Biaya Produksi nilainya 0 atau konstan maka pendapatan nilainya sebesar 4.409.

b) Luas Lahan $\left(X_{1}\right)$

Nilai koefisien regresi luas lahan sebesar 0.094 menyatakan bahwa setiap penambahan 1 persen luas lahan maka akan menyebabkan peningkatan pendapatan petani padi sebesar 0,09 persen. Arah hubungan antara luas lahan dengan pendapatan adalah searah $(+)$, dimana penambahan luas lahan akan mengakibatkan kenaikan pendapatan petani padi. Semakin luas lahan sawah maka akan semakin banyak hasil produksi dan semakin banyak hasil produksi yang dihasilkan maka pendapatan juga akan meningkat. Menurut A.T. Mosher dalam Soekartawi, 2002 Lahan merupakan pabriknya produksi pertanian. Besar kecilnya luas lahan sangat berpengaruh terhadap produksi pertanian dan pendapatan petani.

c) Harga Jual $\left(X_{2}\right)$

Nilai koefisien regresi harga jual sebesar 1.785 menyatakan bahwa setiap penambahan 1 persen harga jual maka akan menyebabkan peningkatan pendapatan petani padi sebesar 1.78 persen. Arah hubungan antara harga jual dengan pendapatan petani padi adalah searah $(+)$, dimana naiknya harga jual gabah akan mengakibatkan kenaikan pendapatan petani padi. Maka semakin tinggi harga gabah maka akan dapat meningkankan pendapatan petani.

d) Hasil Produksi $\left(\mathrm{X}_{3}\right)$

Nilai koefisien regresi hasil produksi sebesar 1.235 menyatakan bahwa setiap penambahan 1 persen hasil produksi maka akan menyebabkan peningkatan pendapatan petani padi sebesar 1.23 persen. Arah hubungan antara hasil produksi dengan pendapatan petani padi adalah searah $(+)$, dimana kenaikan hasil produksi akan mengakibatkan kenaikan pendapatan petani padi. Semakin besar hasil produksi maka pendapatan akan mengalami peningkatan disetiap masa panen.

e) Biaya Produksi $\left(X_{4}\right)$

Nilai koefisien regresi biaya produksi sebesar -0,321 menyatakan bahwa setiap penambahan 1 persen biaya produksi maka akan menyebabkan pendapatan petani padi turun sebesar 0,32 persen. Arah hubungan antara biaya produksi dengan pendapatan petani padi adalah tidak searah $(-)$, dimana kenaikan biaya produksi akan mengakibatkan penurunan pendapatan petani padi. 


\section{Koefisien Determinasi (R2)}

Hasil perhitungan koefisien determinasi penelitian ini dapat terlihat pada Tabel 6 sebagai berikut :

Tabel 2 Hasil Perhitungan Koefisien Determinasi (R square)

Model Summary ${ }^{b}$

\begin{tabular}{lcccr}
\hline Model & R & R Square & Adjusted R Square & Std. Error of the Estimate \\
\hline 1 & .998 & .996 & .996 & .02830 \\
\hline $\begin{array}{l}\text { a. Predictors:(Constant), Biaya Produksi, Harga Jual, Luas Lahan, Hasil Produksi } \\
\text { b. Dependent Variable: pendapatan }\end{array}$ \\
Sumber : Data Primer Diolah, 2019, Output SPSS 24.
\end{tabular}

Berdasarkan output SPSS bahwa hasil dari perhitungan diperoleh nilai koefisien determinasi (RSquare) sebesar 0,996 dengan kata lain hal ini menunjuk-kan bahwa besar persentase variasi pendapatan petani padi yang bisa dijelaskan oleh variasi dari keempat variabel bebas yaitu luas lahan, harga jual, harga produksi dan biaya produksi sebesar 99,6 persen sedangkan sisanya sebesar 0,4 persen dipengaruhi oleh variabel-variabel lain yang tidak dibahas dalam penelitian ini.

\section{Uji Normalitas}

\section{Gambar 1 Grafik Normal P-Plot}

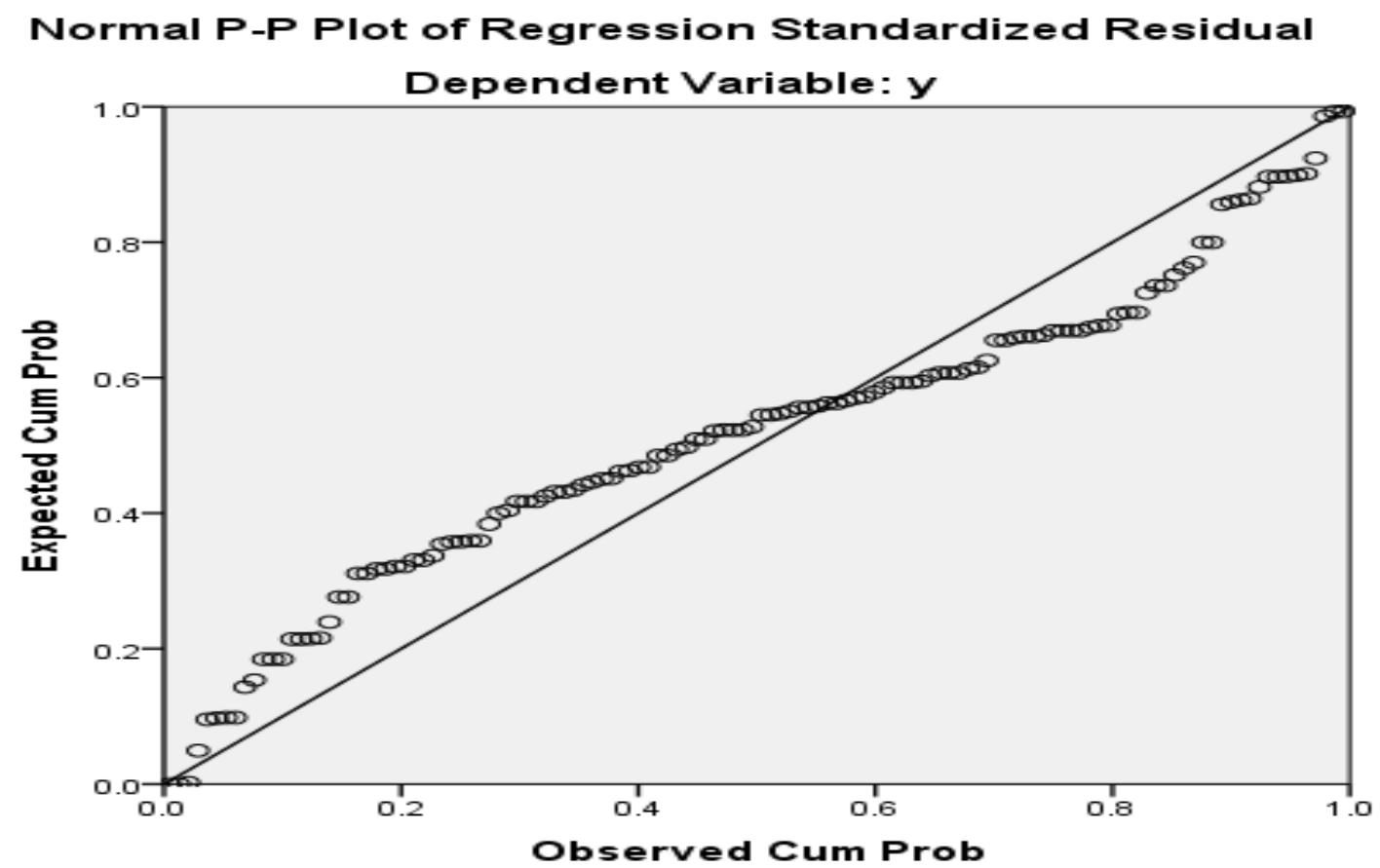

Sumber : Data Primer Diolah, 2019, Output SPSS 24. 


\section{Uji Multikolinieritas}

Tabel 3. Uji Multikolinieritas

Coefficients $^{\mathrm{a}}$

\begin{tabular}{llll}
\hline \multirow{2}{*}{ Model } & \multicolumn{2}{c}{ Collinearity Statistics } \\
\cline { 2 - 4 } & \multicolumn{1}{c}{ Tolerance } & VIF \\
\hline \multirow{2}{*}{ (Constant) } & & 7.574 \\
\cline { 2 - 4 } & Luas Lahan & .132 & 1.311 \\
\cline { 2 - 4 } Hasil Produksi & .763 & 8.799 \\
\cline { 2 - 4 } & Harga Jual & .114 & 3.489
\end{tabular}

a. Dependent Variable: pendapatan

Sumber : Data Primer Diolah, 2019, Output SPSS 24.

a. Uji Autokorelasi

Tabel 4 Hasil Uji Autokorelasi

Model Summary

\begin{tabular}{ccccc}
\hline \multirow{2}{*}{ Model } & \multicolumn{3}{c}{ Change Statistic } & \multirow{2}{*}{ Durbin Watson } \\
\cline { 2 - 4 } & df1 & df2 & Sig. F Cange & \\
\hline 1 & 4 & 121 &, 000 & 1.789 \\
\hline
\end{tabular}

Sumber : Data Primer Diolah, 2019, Output SPSS 24.

b. Uji Heteroskedastisitas

Gambar 2 Uji Heteroskedasitisitas NPI

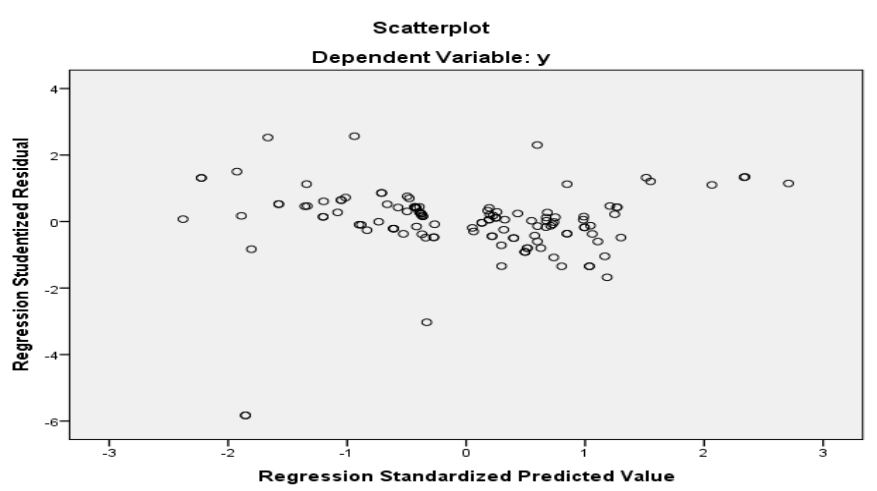

Sumber : Data Primer Diolah, 2019, Output SPSS 24. 


\section{Uji Hipotesis}

a. Uji F

Hasil perhitungan Uji F ini dapat dilihat pada Tabel 3 sebagai berikut:

Tabel 5 Hasil Perhitungan Uji F (Secara Simultan)

\section{ANOVA $^{\mathrm{a}}$}

\begin{tabular}{|c|c|c|c|c|c|c|}
\hline \multicolumn{2}{|c|}{ Model } & \multirow{2}{*}{$\begin{array}{c}\text { Sum of Square1s } \\
26.574\end{array}$} & \multirow{2}{*}{\begin{tabular}{|l|} 
Df \\
4
\end{tabular}} & \multirow{2}{*}{$\begin{array}{c}\text { Mean Square } \\
6.644\end{array}$} & \multirow{2}{*}{$\begin{array}{c}F \\
8295.242\end{array}$} & \multirow{2}{*}{$\begin{array}{l}\text { Sig. } \\
.000\end{array}$} \\
\hline 1 & Regression & & & & & \\
\hline & Residual & .097 & 121 & .001 & & \\
\hline & Total & 26.671 & 125 & & & \\
\hline
\end{tabular}

Dependent Variable: Pendapatan

Predictors: (Constant), Biaya Produksi, Harga Jual, Luas Lahan, Hasil Produksi

Sumber : Data Primer Diolah, 2019, Output SPSS 24.

Berdasarkan hasil regresi pada Tabel 3 diatas menunjukkan pengaruh variabel luas lahan $\left(\mathrm{X}_{1}\right)$, harga jual $\left(\mathrm{X}_{2}\right)$, hasil produksi $\left(\mathrm{X}_{3}\right)$ dan biaya produksi $\left(\mathrm{X}_{4}\right)$ terhadap pendapatan petani padi $(Y)$ dengan nilai $F_{\text {hitung }}$ sebesar 8295.242 dengan signifikansi sebesar 0,000 lebih kecil dari taraf signifikansi yang digunakan dalam penelitian ini yaitu $0,05(0,000<0,05)$ hal ini menunjukkan bahwa keempat variabel bebas secara simultan berpengaruh signifikan terhadap variabel terikat.

b. Uji t

Sementara hasil perhitungan uji t ditunjukkan pada Tabel 4 berikut:

Tabel 6. Hasil Perhitungan Uji t ( Secara Parsial)

Coefficients $^{\mathrm{a}}$

\begin{tabular}{lcccrr}
\hline \multicolumn{1}{c}{ Model } & \multicolumn{2}{c}{ Unstandardized Coefficients } & $\begin{array}{c}\text { Standardized } \\
\text { Coefficients }\end{array}$ & T & Sig. \\
\cline { 2 - 5 } & B & Std. Error & Beta & \\
\hline (Constant) & -4.409 & .618 & - & -7.139 & .000 \\
\hline Luas Lahan & .094 & .020 & .069 & 4.604 & .000 \\
\hline Harga Jual & 1.785 & .075 & .149 & 23.817 & .000 \\
\hline Hasil Produksi & 1.235 & .018 & 1.137 & 69.969 & .000 \\
\hline Biaya Produksi & -.321 & .010 & -.317 & -30.985 & .000 \\
\hline
\end{tabular}

a. Dependent Variable: pendapatan

Sumber : Data Primer Diolah, 2019, Output SPSS 24. 
Tabel yang ada menunjukkan pengaruh secara parsial variabel luas lahan, harga jual, hasil produksi dan biaya produksi terhadap pendapatan petani dapat dilihat dari arah tanda dan tingkat signifikansi dimana variabel tersebut memiliki tingkat signifikansi $<0.05$ dari hasil tersebut dapat ditarik kesimpul-an bahwa variabel independen (luas lahan, harga jual, hasil produksi dan biaya produksi) teradap variabel dependen (pendapatan) berpengaruh secara parsial.

\section{Pengaruh Luas Lahan Terhadap Pendapatan Petani Padi}

Luas lahan berpengaruh signifikan $(0.000<0.05)$ dan berhubungan positif terhadap pendapatan petani. Berdasarkan penelitian dapat diketahui bahwa luas lahan yang digunakan oleh petani padi di Kecamatan Majauleng adalah luas lahan dengan jumlah tertinggi yaitu luas lahan 51 - 100 sebanyak 71 petani dengan persentase 56,3 persen dan luas lahan yang terendah yaitu $\geq 101$ are sebanyak 6 petani dengan persentase 4,8 persen. Hal ini me-nunjukkan bahwa rata-rata petani menggunakan lahan yang yang sudah cukup luas dalam memproduksi padi. Dengan luas lahan yang dimiliki dapat mem-peroleh hasil produksi yang maksimal.

Nilai koefisien regresi luas lahan sebesar 0.094 menyatakan bahwa setiap penambahan 1 persen luas lahan maka akan menyebabkan peningkatan pendapat-an petani padi sebesar 0,09 persen. Arah hubungan antara luas lahan dengan pen-dapatan adalah searah $(+)$, dimana penambahan luas lahan akan mengakibatkan kenaikan pendapatan petani padi. Semakin luas lahan sawah maka akan semakin banyak hasil produksi dan semakin banyak hasil produksi yang dihasilkan maka pendapatan juga akan meningkat. Menurut A.T. Mosher dalam Soekartawi, 2002 Lahan merupakan pabriknya produksi pertanian. Besar kecilnya luas lahan sangat berpengaruh terhadap produksi pertanian dan pendapatan petani.

Hasil penelitian ini sesuai dengan teori yang dikemukakan oleh Mubyarto (1985 : 79) bahwa luas lahan penguasaan lahan bagi rumah tangga petani akan berpengaruh pada produksi usaha tani padi sawah. Jadi dapat disimpulkan bahwa semakin luas lahan yang ditanami padi sawah maka akan berdampak positif pada pendapatan petani.

Hal ini sejalan dengan penelitian yang dilakukan oleh Rusdiah Nasution (2008), yaitu semakin luas lahan yang diusahakan petani maka jumlah produksi pun akan meningkat yang akhirnya akan meningkatkan pendapatan petani. Dan sejalan pula dengan penelitian yang 
telah dilakukan oleh Besse Ani Kasutri (2012) yang menyatakan bahwa jumlah luas lahan sangat berpengaruh dan signifikan terhadap produksi padi di Kabupaten Wajo, luas lahan yang memadai dan didukung dengan tingkat kesuburan tanah yang baik, maka akan meningatkan produski padi yang akan dihasilkan, dan ketika peroduksi meningkat maka pen-dapatan yang akan dihasilkan oleh petani juga meningkat

Adapun yang mempengaruhi pendapatan petani yang dilihat dari luas lahan yaitu antara penggarap lahan dan pemilik lahan, penggarap lahan dikenakan sewa atas lahan yang digarapnya dan bagi pemilik lahan dikenakan pajak atas kepemilikan lahannya.

\section{Pengaruh Harga Jual Terhadap Pendapatan Petani Padi}

Harga jual berpengaruh signifikan $(0.000<0.05)$ terhadap perubahan peningkatan pendapatan petani padi. Sehingga, untuk mendapatkan penambahan hasil pendapatan yang besar harus diikuti dengan harga gabah dalam penjulan dan pemasaran, penambahan harga gabah akan mengurangi biaya ongkos yang akan dikeluarkan oleh petani selama proses produksi sehingga akan mampu meningkatkan pendapatan yang diperoleh. Jika harga gabah terlalu rendah, pendapatan petani juga ikut menurun, dan mereka akan menjadi korban, begitu juga sebaliknya.

Nilai koefisien regresi harga jual sebesar 1.785 menyatakan bahwa setiap penambahan 1 persen harga jual maka akan menyebabkan peningkatan pen-dapatan petani padi sebesar 1.78 persen. Arah hubungan antara harga jual dengan pendapatan petani padi adalah searah $(+)$, dimana naiknya harga jual gabah akan mengakibatkan kenaikan pendapatan petani padi. Maka semakin tinggi harga gabah maka akan dapat meningkankan pendapatan petani.

Penelitian ini juga di dukung oleh penelitian A. Husni Malian dkk. Koefisien dari variabel harga yang diterima petani dari hasil regresi logistic adalah positif, artinya jika harga semakin tinggi akan menyebabkan peluang petani men-jual gabah ke LUEP semakin besar. Hubungan tersebut tidak signifikan karena nilai $P$ variabel harga lebih besar dari 5 persen. Nilai $P$ variabel tingkat pendidikan sebesar 0,394 sehingga sudah cukup bukti untuk mengatakan bahwa harga ber-pengaruh terhadap keputusan petani untuk menjual gabah ke LUEP.

Hasil penelitian ini sesuai dengan teori Cobweb (dalam Mubyarto, 1989 ) yang menya takan bahwa petani sangat responsif terhadap perubahan harga komoditi pertanian, pada waktu harga tinggi petani berusaha menambah produksi komoditi pertanian mereka dan sebaliknya pada waktu harga rendah petani ber-usaha menurunkan produksi. Hal ini berarti 
jika harga jual gabah meningkat dipasaran, maka petani akan berusaha untuk meningkatkan jumlah produksinya, yang dapat dilakukan dengan berbagai cara di antaranya meningkatkan atau memaksimalkan penggunaan input-input produksi dan melakukan pera watan terhadap tanaman padi sawah dengan lebih baik.

Penelitian ini juga di dukung oleh Markita menyatakan harga jual ber-pengaruh sangat signifikan terhadap pendapatan yang ditunjukkan oleh nilai probability kedua variabel tersebut adalah 0,000 , nilai ini lebih kecil dari $a=0,01$. Koefisien regresi variabel produksi sebesar 4620.156 yang menunjukkan bahwa jika produksi meningkat $1 \mathrm{~kg}$ maka pendapatan akan bertambah/meningkat sebesar Rp. 4620.156 Implikasi dari temuan ini adalah bahwa pendapatan usahatani tani masih bisa ditingkatkan melalui peningkatan produktivitas per hektar. Koefisien regresi variabel harga jual sebesar 1093.614, artinya jika terjadi kenaikan pada harga jual sebesar Rp 1 maka pendapatan akan meningkat sebesar Rp 1,093,614. Implikasi dari temuan ini adalah pendapatan petani masih bisa ditingkatkan jika harga ditingkat.

\section{Pengaruh Hasil Produksi Terhadap Pendapatan Petani Padi}

Distribusi responden berdasarkan hasil produksi dalam satukali panen, dengan jumlah tertinggi ada banyak 72 orang yang mem-produksi sebanyak $1.000 \mathrm{Kg}-5.000 \mathrm{Kg}$. Hal ini menunjukkan bahwa tingkat kesejahteraan petani masih rendah karena pendapatan yang diperoleh petani rata-rata hanya berkisar $1.000 \mathrm{Kg}-5.000 \mathrm{Kg}$ dan tingkat pendapatan yang rendah disebabkan karena cuaca dan hama yang menyerang padi di sawah. Hasil produksi merupakan hal yang paling ditunggu oleh para petani, yang mereka harapkan adalah peningkatan hasil produksi di setiap masa panen. Ketika kasil produksi padi itu maksimal maka pendapatan yang akan diperoleh petani juga akan maksimal atau dengan kata lain petani akan memperoleh laba yang banyak.

Hasil produksi berpengaruh signifikan $(0.000<0.05)$ terhadap peningkatan pendapatan petani padi di Kabupaten Wajo Kecamatan Majauleng Desa Botto Benteng. Hasil produksi tertinggi yaitu $1.000 \mathrm{~kg}-5.000 \mathrm{~kg}$ dengan frekuensi 72 orang dengan frekuensi 57 persen. Sedangkan hasil produksi terendah yaitu $15.100 \mathrm{~kg}-20.000 \mathrm{~kg}$ dengan frekuensi 1 orang dengan presentase 0,8 persen. Hal tersebut membuktikan bahwa hasil produksi berpengaruh positif dan signifikan terhadap peningkatan pendapatan petani padi di 
Kecamatam Majauleng karena semakin banyak jumlah produksi yang dihasil-kan maka pendapatan petani akan meningkat.

Nilai koefisien regresi hasil produksi sebesar 1.235 menyatakan bahwa setiap penambahan 1 persen hasil produksi maka akan menyebabkan peningkatan pendapatan petani padi sebesar 1.23 persen. Arah hubungan antara hasil produksi dengan pendapatan petani padi adalah searah $(+)$, dimana kenaikan hasil produksi akan mengakibatkan kenaikan pendapatan petani padi. Semakin besar hasil produksi maka pendapatan akan mengalami peningkatan disetiap masa panen.

Penelitian ini juga didukung oleh Aditya Purnomo, Muhammad Fathorrazi, dan Sebastiana Viphindrartin menyatakan bahwa hasil produksi berpengaruh signifikan terhadap pendapatan petani, dengan menggunakan tingkat signifikan 5 persen dapat diketahui hasil signifikan dan bertanda positif terhadap pendapatan petani. Tanda positif menunjukkan bila hasil bertambah sebesar 1 persen maka pendapatan petani akan bertambah sebesar 0,106189 persen.

\section{Pengaruh Biaya Produksi Terhadap Pendapatan Petani Padi}

Distribusi responden berdasarkan biaya produksi petani, biaya yang dimaksud adalah biaya pupuk dan biaya pengolahan lahan, biaya pembibitan, dan biaya tenaga kerja yang digunakan petani untuk meningkat-kan hasil produksinya. Dengan nilai tertinggi yakni Rp 1.000 .000 - Rp 5.000.000 dengan frekuensi 87 orang. Biaya yang mereka keluarkan itu dilihat dari luas lahan, kepemilikan lahan, dan apakah pemilik lahan itu membajak sendiri lahan pertaniannya.

Biaya produksi berpengaruh signifikan $(0.000<0.05)$ terhadap perubahan pendapatan petani padi. Sehingga, untuk men-dapatkan penambahan pendapatan yang besar harus diikuti dengan biaya produksi dalam melakukan produksi.

Nilai koefisien regresi hasil produksi sebesar -0,321 menyatakan bahwa setiap penambahan 1 persen biaya produksi maka akan menyebabkan pendapatan petani padi turun sebesar 0,32 persen. Arah hubungan antara hasil produksi dengan pendapatan petani padi adalah tidak searah (-), dimana kenaikan biaya produksi akan mengakibatkan penurunan pendapatan petani padi.

Penelitian ini didukung oleh Hesti Mulyati (2014), menyatakan bahwa biaya produksi berpengaruh signifikan terhadap pendapatan petani padi $(0,02<0,05)$. Biaya produksi merupakan korbanan biaya yang dikeluarkan oleh petani untuk setiap kali produksi. Setiap 
kegiatan usahatani tidak pernah terlepas dari biaya variable dan biaya tetap untuk ,mengelolah usahataninya agar memperoleh hasil yang diharapkan.

\section{KESIMPULAN / CONCLUSION}

Berdasarkan hasil penelitian dari hasil data dilapangan dapat disimpulkan bahwa pengaruh variabel modal terhadap tingkat pendapatan pedagang adalah positif. Variabel luas lahan (X1), harga jual (X2), hasil produksi (X3), dan biaya produksi (X4) secara simultan berpengaruh signifikan dan berhubungan positif terhadap terhadap tingkat pendapatan petani padi di Desa Botto Benteng Kecamatan Majauleng Kabupaten Wajo. Variabel luas lahan berpengaruh signifikan dan berhubungan positif terhadap tingkat pendapatan petani padi di Desa Botto Benteng Kecamatan Majauleng Kabupaten Wajo. Variabel harga jual berpengaruh signifikan dan berhubungan positif terhadap tingkat pendapatan petani padi di Desa Botto Benteng Kecamatan Majauleng Kabupaten Wajo. Variabel hasil produksi berpengaruh signifikan dan berhubungan positif terhadap tingkat pendapatan petani padi di Desa Botto Benteng Kecamatan Majauleng Kabupaten Wajo. Variabel biaya produksi berpengaruh signifikan dan berhubungan negatif terhadap tingkat pendapatan petani padi di Desa Botto Benteng Kecamatan Majauleng Kabupaten Wajo.

Untuk meningkatkan produksi bagi petani, dari pihak pemerintah ataupun swasta harus mengarahkan petani dalam hal pemasaran hasil panen yang diperoleh serta cara penggunaan teknologi dibidang produksi baik itu secara kualitas maupun kuantitasnya. Sehingga hasil produksi yang diper-oleh petani mengalami peningkatan setiap satu kali panen. Selain itu, petani sebaiknya membentuk kelompok tani ataupun koperasi yang dapat membantu dalam hal memperoleh pinjaman modal, membantu pemasaran hasil produksinya, dan tukar ilmu serta informasi antar petani agar petani dapat lebih mandiri.

\section{DAFTAR PUSTAKA / REFERENCES}

Alvio G, Onibala, Mex L. Sondakh, Rine Kaunang, dan Juliana, Mandei. 2017. Analisis FaktorFaktor Yang Mempengaruhi Produksi Padi Sawah Di Kelurahan Koya, Kecamatan Tondano Selatan. Jurnal Studi Ekonomi Pembangunan.

Badan Pusat Statisik Kabupaten Wajo. 2018. Wajo. 
Bustos, P., Caprettini, B., \& Ponticelli, J. (2016). Agricultural Productivity and Structural Transformation: Evidence from Brazil. American Economic Review.

Dominick, Salvatore. 2008. Mikro Ekonomi Edisi Keempat, Jakarta: Erlangga.

Anwar, A.F. and Nursini, N., 2018. Mengungkap Penghidupan Petani Miskin Pedesaan;

Sebuah Kajian Sosial Ekonomi. EcceS (Economics, Social, and Development Studies), 5(1), pp.1-21.

Gollin, Douglas, Stephen Parente, and Richard Rogerson. 2002. The Role of Agriculture in Development. American Economic Review.

Gregory Mankiw. 2007. Makro Ekonomi, Jakarta, Penerbit Erlangga.

Kongsamut, Piyabha, Sergio Rebelo, and Danyang Xie. 2001. Beyond Balanced

Growth."Review of Economic Studies.

M. L. Jhingan. 2012. Ekonomi Pembangunan dan Perencanaan Edisi 1, Jakarta: Rajawali Pers.

Mowen, Hansen. 2004. Manajemen Biaya. Edisi Bahasa Indonesia. Buku Kedua, Jakarta:

Salemba Empat.

Muhammad Teguh. 2009. Ekonomi Industri, Jakarta, PT.Grafindo Persada.

Mulyati, Hesti. 2014. Analisis Produksi dan Pendapatan Usaha Tani Padi Sawah Desa Jono

Oge Kecamatan Sigi Biromaru Kabupaten Sigi, Jurnal Agribisnis.

Murphy, Kevin M., Andrei Shleifer, and Robert Vishny. 1989. Income Distribution, Market

Size, and Industrialization. Quarterly Journal of Economics.

Nurkse, Ragnar. 1953. Problems of Capital Formation in Underdeveloped Countries. Oxford:

Basil Blackwell.

Puguh, Apriadi. 2015. Analis Pengaruh Modal, Jumlah Hari Kerja, Luas Lahan, Pelatihan, Dan

Teknologi Terhadap Pendapatan Petani Padi Dikecamatan Gambiran Kabupaten

Banyuwangi. Jurnal Studi Ekonomi Pebangunan

Rahim. 2007.Ekonomika Pertanian (Pengantar, Teori dan Kasus), Jakarta. Penebar Swadaya.

Rostow, W. W. 1960. The Stages of Economic Growth: A Non Communist Manifesto.

London: Cambridge University Press.

Sakirno, Sadono. 2013. Mikro Ekonomi : teori pengantar edisi ketiga, Jakarta: PT Raja Grafindo Persada.

Schultz, Theodore W. 1953. The Economic Organization of Agriculture. New York: Mc GrawHill.

Silvira, Hasman dan Fauzia. 2014. Analisis Faktor-Faktor Yang Mempengaruhi Produksi Padi Sawah (Studi Kasus: Desa Medang, Kecamatan Medang Deras, Kabupaten Batu Bara. 
Soekartawi. 2003. Prinsip Ekonomi Pertanian. Raja Grafindo Persada. Jakarta.

Sudantoko, D dan Hamdani.2009. Dasar-Dasar Ekonomi Pembangunan Edisi Pertama. Jakarta.

Suratiyah, Ken. 2006. Ilmu Usaha Tani. Penebar Swadaya : Jakarta.

Suryana dkk. 2001. Bunga Rampai Ekonomi, Jakarta, LPEM-FEUI.

Todaro. 2003. Pembangunan Ekonomi di Dunia Ketiga, Jakarta, Erlangga. 